\title{
KERAGAMAN SIFAT KUALITATIF AYAM KAMPUNG DI MINAHASA
}

\author{
Monika Kolompoy, Lucia J. Lambey*, Umar Paputungan, E. S. Tangkere \\ Fakultas Peternakan Universitas Sam Ratulangi Manado
}

\begin{abstract}
ABSTRAK
Penelitian ini bertujuan untuk mengetahui keragaman sifat kualitatif ayam kampung di Kabupaten Minahasa. Sebanyak 292 ekor ayam dewasa digunakan sebagai sampel yang diambil secara acak dan dianalisis menggunakan metode deskriptif. Hasil penelitian menunjukkan bahwa frekuensi fenotip dan genotip warna dan pola bulu 0,000515 , bentuk jengger 0,000458, warna cupping 0,9957, warna kulit kaki 0,9949, dan bentuk taji 0,000193. Derajat nilai heterosigositas sifat-sifat kualitatif ayam Kampung di Minahasa rata-rata berada dalam ketegori sedang $(0,20)$ sampai tinggi $(0,50)$. Derajat nilai heterosigositas sifat sifat fenotip ayam kampung di Minahasa mengindikasikan derajat perkawinan inbreeding relatif rendah. Sebaran pewarisan fenotip sifat warna bulu, bentuk jengger dan bentuk taji kaki jantan berdasarkan sampel populasi ayam kampung tidak berada dalam keseimbangan genetik. Sifat kualitatif ayam kampung di Kabupaten Minahasa menunjukan tingkat keberagaman yang cukup tinggi.
\end{abstract}

Kata kunci: ayam kampung, sifat kualitatif.

\section{ABSTRACT \\ THE DIVERSITY OF QUALITATIVE CHARACTERISTICS IN NATIVE CHICKEN AROUND}

*Korespondensi (corresponding author) Email: lucialambey@yahoo.com
MINAHASA. This study aims to determine the diversity of qualitative characteristics in native chicken around Minahasa Regency. A total of 292 adult chickens were used as samples taken randomly and analyzed using descriptive methods. The results showed that the phenotype frequency, color genotype and feather pattern were 0.000515 . Trait frequencies of comb shape was 0.000458 , cupping color was 0.9957 , foot skin color was 0.9949 , and spur shape was 0.000193 . The degree of heterosigosity of qualitative characteristics of Kampung chickens in Minahasa on average was in the medium category $(0.20)$ to high $(0.50)$. The degree of heterosigosity of the phenotypic traits of native chicken in Minahasa indicated the relative low degree of inbreeding mating. Distribution of phenotypic inheritance of feather color, comb shape and shape of male foot spurs based on samples of native chicken populations were not in genetic equilibrium. The qualitative traits of native chickens in the Minahasa Regency showed a fairly high level of diversity.

Key words: native chicken, qualitative characteristics.

\section{PENDAHULUAN}

Salah satu sumber kekayaan genetik ternak Indonesia adalah ayam kampung. Kebutuhan gizi masyarakat Indonesia terlebih masyarakat yang tinggal di pedesaan, salah satunya dapat dipenuhi dengan produk ayam kampung berupa telur 
dan daging (Naatamijaya, 2010). Ayam kampung dapat dengan mudah dijumpai di Sebagian rumah warga dikarenakan pemeliharaannya yang cukup mudah dan tidak membutuhkan modal besar, juga karena ayam kampung memiliki kemampuan beradaptasi yang baik dengan lingkungan. Penampilan ayam kampong sangat beragam, begitu pula sifat genetiknya, penyebarannya sangat luas karena ayam kampung dapat dijumpai di kota maupun di desa (Nangoy et al., 2017). Tahapan karakteristik ternak yang pertama kali dilakukan adalah dengan menggunakan karakteristik genetik eksternal. Tahapan ini merupakan langkah dasar yang dilakukan untuk menentukan jenis ternak yang diwariskan pada generasi berikutnya (Rafian dan Ulupi, 2017). Karakteristik eksternal yang diamati meliputi sifat kualitatif seperti warna bulu, bentuk jengger, warna cuping dan warna kulit kaki. Munculnya warna bulu, bentuk jengger, warna cupping dan warna kulit kaki yang bukan karakteristik ayam kampung menandakan bahwa ayam kampung yang dipelihara merupakan hasil persilangan (Arlina et al, 2014). Variasi genetik yang tinggi dari ayam kampung menandakan adanya potensi untuk dilakukan perbaikan mutu genetik pada ayam kampung. Maka dari itu diperlukan data dasar mengenai sifat sifat kualitatif ayam kampung untuk mempertahankan kemurnian dan pelestariannya (Subekti dan Arlina, 2011; Sartika et al., 2008).

Berdasarkan uraian diatas, telah dilakukan penelitian mengenai keragaman sifat kualitatif ayam kampung yang ada di Minahasa.

\section{MATERI DAN METODE PENELITIAN}

\section{Waktu dan Lokasi Penelitian}

Penelitian ini dilaksanakan di Kabupaten Minahasa dengan sampel tempat pengamatan di berapa Kecamatan, yakni Pineleng, Kawangkoan, Tompaso dan Tondano pada bulan Desember 2019 sampai bulan Februari 2020.

\section{Materi Penelitian}

Materi yang digunakan adalah ayam kampung jantan dan betina yang berumur 6 bulan ke atas telah mencapai dewasa kelamin sebanyak 292 ekor.

\section{Alat Penelitian}

Alat yang digunakan adalah tabel pengamatan, alat tulis, dan kamera handphone.

\section{Metode Penelitian}

Metode penelitian yang digunakan adalah metode survei terhadap tampilan phenotipe ayam yang dapat diwariskan secara genetik. Pengambilan sampel dilakukan secara puposive sampling pada kecamatan yang banyak memiliki populasi ayam kampung dan dilanjutkan dengan 
pengambilan sampel secara simple random terhadap ternak. Data diperoleh dengan melakukan pengamatan langsung terhadap sifat kualitatif sesuai variable dengan berdasarkan frekuensi perjumpaan sifat kualitatif pada populasi ayam. Perhitungan frekuensi dan heterosigositas digunakan untuk mengetahui tingkat keberagaman ayam kampung.

Untuk menguji keseimbangan genetik dari hasil observasi (actual) telah dilakukan perbandingan dengan nilai harapan (expected) yang kemudian dianalisis melalui program Microsoft excel memakai (Chi square test) atau secara manual dengan rumus (Byrkit, 1987) sebagai berikut:

$$
\chi^{2}=\sum \frac{\left(f_{o}-f_{e}\right)^{2}}{f_{e}}
$$

Dimana, $X^{2}$ adalah distribusi Chi-square, $f_{o}$ adalah frekuensi observasi sifat ternak (fenotip dan genotip) setiap variabel pengamatan, dan $f_{e}$ adalah frekuensi harapan sifat ternak.

Frekuensi genotip dari populasi individu dalam keseimbangan genetik memiliki rumus (Van Vleck, 1987):

$$
1=\mathrm{p}^{2}+2 \mathrm{pq}+\mathrm{q}^{2}
$$

Dimana, $\mathrm{p}=$ frekuensi gen dominan sifat kualitatif, $\mathrm{q}=$ frekuensi gen resesif sifat kualitatif.

Frekuensi gen dalam keseimbangan genetik memiliki rumus:

$$
1=\mathrm{p}+\mathrm{q}
$$

Dimana, $\mathrm{p}=$ frekuensi gen dominan, $\mathrm{q}=$ frekuensi gen resesif.

Kemudian dihitung frekuensi gen fenotipe dengan menggunakan rumus Noor (2008):

$$
\mathrm{p}=1-\mathrm{q}
$$

Berdasarkan rumus frekuensi genotip, nilai q dapat dianalisis dengan melibatkan jumlah sifat fenotipe individu ternak yang memiliki sifat kualitatif genotip homosigot resesif melalui rumus (Van Vleck, 1987):

$$
\mathrm{q}=\sqrt{ } \mathrm{q}^{2}=\left(\sum n_{i i} / \mathrm{N}\right)^{1 / 2}
$$

$\sum n_{i i}=$ jumlah ternak ayam dengan genotip homosigot resesif,

$\mathrm{N}=$ total ternak ayam

Hasil frekuensi gen diuji untuk mengetahui keragamannya dengan melihat nilai heterozigositas berdasarkan rumus sebagai berikut:

$$
\mathrm{H}=1-\sum x^{2}
$$

Keterangan

$\mathrm{H}=$ harapan heterozigositas individu

$\Sigma=$ jumlah individu

$x_{i}=$ nilai frekuensi gen dominan dan frekuensi gen resesif

\section{Parameter Penelitian}

1. Warna dan pola bulu

2. Bentuk jengger

3. Warna cuping

4. Warna kulit kaki

5. Bentuk taji kaki pada ayam jantan 


\section{HASIL DAN PEMBAHASAN}

Pengamatan sifat kulitatif ayam dianalisis tentang keseimbangan genotip sifat-sifat ternak ayam dalam wilayah pengamatan khusus pada warna bulu Berdasarkan uji Chi square, diperoleh bahwa distribusi genotipe ternak ayam kampung dalam sifat ini adalah tidak berada dalam keseimbangan genetik $(\mathrm{P}<0,01)$. Secara teori, dasar pewarisan Mendel dari persilangan antara semua individu bergenotipe homosigot dan heterosigot menghasilkan semua anak bergenotipe homosigot dominan dengan heterosigot yang sama dengan kedua tetua mereka, dan demikian pula persilangan antara individu bergenotipe homosigot resesif dengan individu bergenoti pehomosigot dominan menghasilkan semua anak bergenotipe heterosigot, namun berada dalam kondisi distribusi genotip populasi yang tidak dalam keberim bangan genotipe (Rifa'i, 2010). Untuk mengembalikan pada kondisi keseimbangan genetik (genetic equilibrium), maka diperlukan kebijakan pengembalian stabilitas populasi ternak dengan metode perkawinan acak secara alami tanpa adanya seleksi sifat tertentu yang dikembangbiakan dengan tidak melibatkan sifat sifat warna secara lengkap (Tamzil et al., 2013)

\section{Frekuensi Fenotip dan Genotip Bentuk Jengger Ayam Jantan dan Betina}

Analisis frekuensi fenotip dan genotip bentuk jengger ayam jantan dan

Tabel 1. Frekuensi Fenotip dan Genotip Warna Bulu Ayam Jantan \& Betina Hasil Observasi Di Kabupaten Minahasa

\begin{tabular}{|c|c|c|c|c|c|c|c|}
\hline \multirow{2}{*}{$\begin{array}{l}\text { Total ayam } \\
\text { jantan \& } \\
\text { betina hasil } \\
\text { observasi } \\
\text { warna bulu }\end{array}$} & \multirow[b]{2}{*}{ Data } & \multicolumn{5}{|c|}{$\begin{array}{l}\text { Frekuensi Fenotip dan Genotip Warna Bulu Ayam } \\
\text { Jantan \& Betina }\end{array}$} & \multirow[b]{2}{*}{$\begin{array}{l}\text { Chi-test } \\
\text { Value }\end{array}$} \\
\hline & & $\begin{array}{c}\text { Liar } \\
\left(i^{\mathrm{W}-i^{b b}}\right)\end{array}$ & $\begin{array}{c}\text { Kolumbian } \\
\left(\mathrm{i}^{\left.\mathrm{W}-\mathrm{i}^{\mathrm{B}}-\right)}\right)\end{array}$ & $\frac{\text { Hitam }}{\left(i^{w w_{i}{ }^{B-}}\right)}$ & $\begin{array}{c}\text { Putih } \\
\left(\mathrm{I}^{-}\right)\end{array}$ & Total & \\
\hline & Obs & 88 & 67 & 9 & 3 & 167 & \multirow{4}{*}{0,000515} \\
\hline Jantan & Exp & 78 & 61 & 26 & 2 & 167 & \\
\hline & Obs & 48 & 40 & 37 & 0 & 125 & \\
\hline Betina & Exp & 58 & 46 & 20 & 1 & 125 & \\
\hline \multicolumn{2}{|c|}{ Total Observasi atau } & 136 & 107 & 46 & 3 & 292 & \\
\hline
\end{tabular}


Tabel 2. Frekuensi Fenotip dan Genotip Bentuk Jengger Ayam Jantan \& Betina Hasil Observasi Di Kabupaten Minahasa

\begin{tabular}{|c|c|c|c|c|c|c|c|}
\hline \multirow{2}{*}{$\begin{array}{l}\text { Total ayam } \\
\text { jantan \& } \\
\text { betina hasil } \\
\text { observasi } \\
\text { bentuk } \\
\text { jengger }\end{array}$} & \multirow[b]{2}{*}{ Data } & \multicolumn{5}{|c|}{$\begin{array}{l}\text { Frekuensi Fenotip dan Genotip Bentuk Jengger Ayam } \\
\text { Jantan \& Betina }\end{array}$} & \multirow[b]{2}{*}{$\begin{array}{c}\text { Chi-test } \\
\text { Value }\end{array}$} \\
\hline & & $\begin{array}{c}\text { Walnut/ } \\
\text { Bantal } \\
\left(\mathrm{R} \_\mathrm{P} \_\right)\end{array}$ & $\begin{array}{c}\text { Mawar/ } \\
\text { Stroberi } \\
\text { (R_pp) }\end{array}$ & $\begin{array}{c}\text { Kacang/P } \\
\text { olong } \\
\text { (rrP_) }\end{array}$ & $\begin{array}{c}\text { Single/ } \\
\text { Tunggal } \\
\text { (rrpp) }\end{array}$ & Total & \\
\hline \multirow[t]{2}{*}{ Jantan } & Obs & 7 & 34 & 90 & 36 & 167 & \multirow{5}{*}{0,000458} \\
\hline & Exp & 18 & 21 & 97 & 31 & 167 & \\
\hline \multirow[t]{2}{*}{ Betina } & Obs & 25 & 3 & 79 & 18 & 125 & \\
\hline & Exp & 14 & 16 & 72 & 23 & 125 & \\
\hline \multicolumn{7}{|c|}{ Total Observasi atau } & \\
\hline
\end{tabular}

Keterangan: Obs = Observasi (actual); Exp = Expected. Chi-testvalue $(0,000458)<$ Chisquare $_{\text {Critiical Value }(0,01)}$; menunjukkan frekuensi Fenotip dan Genotip Bentuk Jengger tidak berada dalam keseimbangan genetik $(\mathrm{P}<0,01)$ berdasarkan Chi-test di Kabupaten Minahasa.

betina disajikan dalam Tabel 2. Hasil uji Chi square menunjukkan bahwa distribusi genotipe ternak ayam kampung dalam kajian pewarisan gen bentuk jengger ayam ini adalah tidak berada dalam keseimbangan genetik $\quad(\mathrm{P}<0,01)$ berdasarkan Chi-test di Kabupaten Minahasa (Tabel 2). Berbeda dengan hasil yang didapat oleh Dako et al. (2020) dalam penelitiannya dimana bentuk jengger ayam kampong berada dalam keseimbangan genetik.

\section{Frekuensi Fenotip dan Genotip Warna Kuping Ayam Jantan dan Betina}

Berdasarkan analisis frekuensi fenotip dan genotip warna kuping ayam jantan dan betina hasil observasi di Kabupaten Minahasa disajikan dalam Tabel 3. Hasil uji Chi Square (Tabel 3), diperoleh bahwa frekuensi genotipe warna cuping ayam jantan dan betina adalah berada dalam keseimbangan genetik $(\mathrm{P}>0,05)$. Jika dalam populasi terjadi perkawinan alamiah secara acak, tanpa mutasi dan seleksi maka frekuensi gen ditiap generasi menjadi tetap (keseimbangan genetik) (Dako et al., 2020).

\section{Frekuensi Fenotip dan Genotip Warna Kulit Kaki}

Berdasarkan uji Chi Square (Tabel 4), diperoleh bahwa frekuensi genotipe 
Tabel 3. Frekuensi Fenotip dan Genotip Warna Kuping Ayam Jantan \& Betina Hasil Observasi Di Kabupaten Minahasa

\begin{tabular}{|c|c|c|c|c|c|c|}
\hline \multirow[b]{2}{*}{$\begin{array}{c}\text { Total Ayam } \\
\text { Jantan \& } \\
\text { Betina Hasil } \\
\text { Observasi } \\
\text { Warna Kuping }\end{array}$} & \multirow[b]{2}{*}{ Data } & \multicolumn{4}{|c|}{$\begin{array}{l}\text { Frekuensi Fenotip dan Genotip Warna Kuping } \\
\text { Ayam Jantan \& Betina }\end{array}$} & \multirow[b]{2}{*}{$\begin{array}{l}\text { Chi-test } \\
\text { Value }\end{array}$} \\
\hline & & $\begin{array}{c}\text { Warna } \\
\text { Kuping } \\
\text { merah } \\
\left(\mathrm{K}^{\mathrm{M}} \mathrm{K}^{\mathrm{M}}\right)\end{array}$ & $\begin{array}{c}\text { Kuping } \\
\text { Putih- } \\
\text { merah } \\
\left(\mathrm{K}^{\mathrm{M}} \mathrm{K}^{\mathrm{m}}\right)\end{array}$ & $\begin{array}{c}\text { Warna } \\
\text { Kuping } \\
\text { Putih } \\
\left(\mathrm{K}^{\mathrm{m}} \mathrm{K}^{\mathrm{m}}\right)\end{array}$ & Total & \\
\hline & Obs & 153 & 14 & 0 & 167 & \multirow{3}{*}{0,9957} \\
\hline Jantan & Exp & 154 & 13 & 0 & 167 & \\
\hline Betina & $\begin{array}{l}\text { Obs } \\
\text { Exp }\end{array}$ & $\begin{array}{l}116 \\
115\end{array}$ & $\begin{array}{c}9 \\
10\end{array}$ & $\begin{array}{l}0 \\
0\end{array}$ & $\begin{array}{l}125 \\
125\end{array}$ & \\
\hline $\begin{array}{r}\text { Total Observa } \\
\text { Expektas }\end{array}$ & i atau & 269 & 23 & 0 & 292 & \\
\hline
\end{tabular}

Tabel 4. Frekuensi Fenotip dan Genotip Warna Kulit Kaki Ayam Jantan \&Betina Hasil Observasi Di Kabupaten Minahasa

\begin{tabular}{|c|c|c|c|c|c|}
\hline \multirow{2}{*}{$\begin{array}{c}\text { Total Ayam } \\
\text { Jantan \& } \\
\text { Betina Hasil } \\
\text { Observasi } \\
\text { Warna Kulit } \\
\text { Kaki }\end{array}$} & \multirow[b]{2}{*}{ Data } & \multicolumn{3}{|c|}{$\begin{array}{l}\text { Frekuensi Fenotip dan Genotip Warna Kulit Kaki } \\
\text { Ayam Jantan \& Betina }\end{array}$} & \multirow{2}{*}{$\begin{array}{l}\text { Chi-test } \\
\text { Value }\end{array}$} \\
\hline & & $\begin{array}{c}\text { Warna } \\
\text { Kulit Kaki } \\
\text { PutihatauKuning }\left(\mathrm{I}_{-}^{\mathrm{d}}\right)\end{array}$ & $\begin{array}{c}\text { Warna } \\
\text { Kuli Kaki Hitam } \\
\text { atau Abuabu( }\left(\mathrm{i}^{\mathrm{d}^{-}}\right)\end{array}$ & Total & \\
\hline & Obs & 124 & 43 & 167 & \multirow{4}{*}{0,9949} \\
\hline Jantan & $\operatorname{Exp}$ & 123 & 44 & & \\
\hline Betina & Obs & 92 & 33 & 125 & \\
\hline & Exp & 93 & 32 & & \\
\hline \multicolumn{2}{|c|}{ Total Observasi atau } & 216 & 76 & 292 & \\
\hline
\end{tabular}

warna kulit kaki ayam jantan dan betina adalah berada dalam keseimbangan genetik $(\mathrm{P}>0,05)$. Hasil penelitian ini berbeda dengan hasil yang didapat oleh Dako et al. (2020) dalam penelitiannya sifat warna kulit kaki tidak berada dalam 
Tabel 5. Frekuensi Fenotip dan Genotip Bentuk Taji Kaki Ayam Jantan Hasil Observasi Di Kabupaten Minahasa

\begin{tabular}{ccccccc}
\hline Total Ayam & \multicolumn{4}{c}{ Frekuensi Fenotip dan Genotip Bentuk Taji Kaki } & & Chi-test \\
$\begin{array}{c}\text { Jantan Hasil } \\
\text { Observasi } \\
\begin{array}{c}\text { Bentuk Taji } \\
\text { Kaki }\end{array}\end{array}$ & Data & $\begin{array}{c}\text { Bentuk } \\
\text { Taji Kaki } \\
\text { Tajam } \\
\left(\mathrm{K}^{\mathrm{T}} \mathrm{K}^{\mathrm{T}}\right)\end{array}$ & $\begin{array}{c}\text { Bentuk Taji } \\
\text { Kaki } \\
\text { Keplek } \\
\left(\mathrm{K}^{\mathrm{T}} \mathrm{K}^{\mathrm{t}}\right)\end{array}$ & $\begin{array}{c}\text { Bentuk } \\
\text { Tanpa } \\
\text { Taji }\left(\mathrm{K}^{\mathrm{t}} \mathrm{K}^{\mathrm{t}}\right)\end{array}$ & Total & \\
\hline \multirow{2}{*}{ Jantan } & Obs & 47 & 53 & 67 & 167 & 0,000193 \\
\hline
\end{tabular}

Keterangan: Obs = Observasi (actual); Exp = Expected berdasarkan rasio F2 kawin acak

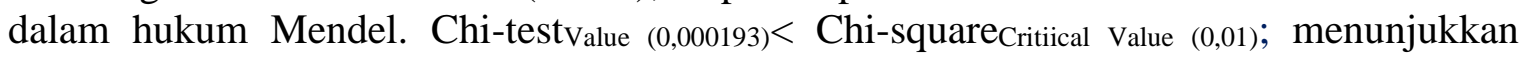
frekuensi Fenotip dan Genotip Bentuk Taji Kaki Ayam Jantan tidak berada dalam keseimbangan genetik $(\mathrm{P}<0,01)$ berdasarkan Chi-test di Kabupaten Minahasa.

keseimbangan genetik.

Untuk menjaga pada kondisi keseimbangan genetik maka diperlukan warna kulit kaki yang dikembangbiakan melalui persilangan alam secara acak (Tamzil et al., 2013).

\section{Frekuensi Fenotip dan Genotip Bentuk Taji Kaki Ayam Jantan}

Berdasarkan uji Chi Square (Tabel 5), diperoleh bahwa frekuensi genotipe bentuk taji kaki ayam jantan adalah tidak berada dalam keseimbangan genetik $(\mathrm{P}<0,01)$ dengan didominasi jumlah ayam jantan dengan bentuk kaki tanpa taji genotip homosigot recesif $\left(\mathrm{K}^{\mathrm{t}} \mathrm{K}^{\mathrm{t}}\right)$. Hal ini dapat terjadi karena adanya mutasi maupun seleksi yang dilakukan oleh peternak sehingga menyebabkan sifat ini tidak kebijakan pengembangbiakan populasi ternak dengan metode perkawinan acak secara alami tanpa adanya seleksi sifat berada dalam keseimbangan genetik, karena diketahui bahwa seleksi dan mutasi merupakan faktor yang mempengaruhi keseimbangan genetik (Dako et al., 2020; Tamzil et al, 2013).

\section{Frekuensi Gendan Heterosigositas Sifat Sifat Dalam Populasi Ternak}

Estimasi nilai heterosigositas dalam populasi ternak ayam menunjukkan bahwa gen untuk sifat sifat ternak yang diamati dapat bersifat "polymorphic" dalam kajian populasi ternak ayam Kabupaten Minahasa. Rataan heterosigositas hasil observasi dalam kajian yang bervariasi dalam penelitian ini dan masih lebih rendah (0.42) 
Tabel 6. Frekuensi Gen dan Heterosigositas Sifat Warna dan Pola Bulu pada Ayam Kampung di Minahasa

\begin{tabular}{|c|c|c|c|c|c|c|}
\hline Fenotipe & Sex & $\mathrm{n}$ & $\%$ & $\mathrm{p}$ & $q$ & $\mathrm{H}$ \\
\hline \multirow[t]{2}{*}{ Liar } & $\hat{0}$ & 88 & 52,69 & 0,27 & 0,73 & 0,40 \\
\hline & q & 48 & 38,4 & 0,38 & 0,62 & 0,47 \\
\hline \multirow[t]{2}{*}{ Kolumbian } & $\widehat{0}$ & 67 & 40,12 & 0,37 & 0,63 & 0,46 \\
\hline & o & 40 & 32 & 0,43 & 0,57 & 0,49 \\
\hline \multirow[t]{2}{*}{ Hitam } & $\hat{0}$ & 9 & 5,39 & 0,77 & 0,23 & 0,36 \\
\hline & 우 & 37 & 29,6 & 0,46 & 0,54 & 0,50 \\
\hline Putih & $\begin{array}{l}0^{1} \\
\text { q }\end{array}$ & 3 & 1,80 & 0,87 & 0,13 & 0,23 \\
\hline
\end{tabular}

Keterangan: $\mathrm{n}$; jumlah sampel $\delta^{1}$ : jantan (167),,+ betina (125), p: frekuensi gen dominan, q: frekuensi gen resesif, $\mathrm{H}$ : heterosigositas

dibandingkan heterosigositas yang diharapkan sekitar 0,50 (Dorak, 2006; Nishida et al., 1982; Mansjoer., 1985). Derajat heterogenitas genetik yang rendah dapat mengarahkan pada kondisi peluang terjadi inbreeding agak tinggi dalam populasi (Rafian dan Ulupi, 2017). Selanjutnya, derajat inbreeding tinggi dalam populasi dapat menyebabkan hybrid vigour ternak menurun (Noor, 2008). Dorak (2006) melaporkan bahwa nilai minimum polimorfisme untuk diterima secara umum adalah 1\%. Angka polimorfisme ini membuktikan bahwa pada ternak ayam Kampung terdapat variasi yang cukup tinggi pada lokus sifat sifat ternak yang membuka peluang untuk menggunakan genotipe sifat sifat gen pada kriteria seleksi.

\section{Warna dan Pola Bulu pada Ayam Kampung}

Frekuensi genetik dan heterosigositas warna dan pola bulu pada ayam Kampung di Minahasa menunjukkan adanya variasi seperti terlihat pada Tabel 6 . Nilai heterosigositas warna bulu ayam Kampung di Minahasa berkisar 0,23 sampai sampai 0,50 yang dapat tergolong sedang sampai tinggi dan mengidikasikan derajat perkawinan inbreeding cukup rendah (Noor, 2008). Bila dibandingkan dengan hasil penelitian Subekti dan Arlina (2011) maka hasil penelitian ini tidak terlalu berbeda dimanawarna bulu ayam Kampung yang paling banyak ditemui adalah warna bulu tipe bulu liar jantan yaitu $38 \%$ dan betina $5 \%$.

Warna dan pola bulu ayam kampung dalam penelitian ini bervariasi, 
Tabel 7. Frekuensi Genetik dan Heterosigositas Bentuk Jengger pada Ayam Kampung di Minahasa

\begin{tabular}{|c|c|c|c|c|c|c|}
\hline Fenotipe & Sex & $\mathrm{N}$ & $\%$ & $\mathrm{p}$ & $q$ & $\mathrm{H}$ \\
\hline \multirow[t]{2}{*}{ Polong } & $\overline{0}$ & 90 & 53,89 & 0,43 & 0,57 & 0,49 \\
\hline & q & 79 & 63,2 & 0,21 & 0,79 & 0,33 \\
\hline \multirow[t]{2}{*}{ Tunggal } & $0^{\pi}$ & 36 & 21,56 & 0,64 & 0,36 & 0,46 \\
\hline & o & 18 & 14,4 & 0,66 & 0,34 & 0,45 \\
\hline \multirow[t]{2}{*}{ Bantal } & 0 & 6 & 3,59 & 0,85 & 0,15 & 0,25 \\
\hline & q & 25 & 20 & 0,60 & 0,4 & 0,48 \\
\hline \multirow[t]{2}{*}{ Mawar } & 0 & 28 & 16,77 & 0,68 & 0,32 & 0,43 \\
\hline & q & 3 & 2,4 & 0,86 & 0,14 & 0,24 \\
\hline \multirow[t]{2}{*}{ Stroberi } & $0^{\pi}$ & 6 & 3,59 & 0,85 & 0,15 & 0,25 \\
\hline & q & & & & & \\
\hline \multirow[t]{2}{*}{ Kacang } & 0 & 1 & 0,60 & 0,94 & 0,06 & 0,11 \\
\hline & q & & & & & \\
\hline
\end{tabular}

Keterangan: $\mathrm{n}$; jumlah sampel $\widehat{\delta}$ : jantan (167),, : betina (125), p: frekuensi gen dominan, q: frekuensi gen resesif, $\mathrm{H}$ : heterosigositas

dengan empat warna, yakni liar dengan hitam kemerahan, Kolumbian, Hitam dan putih. Amlia et al. (2016) menyatakan bahwa warna bulu ayam kampung sangat bervariasi dengan kata lain penampilan fenotipnya masih sangat beragam. Tingkat pada ayam kampung yang ada di Minahasa masih sangat tinggi. Hal ini dapat dilihat darinilai hetrozigositas yang terdapat pada Tabel 6 menunjukkan nilai heterozigositas diatas angka 0,01. Nei dan Kumar (2000) menyatakan bahwa suatu populasi dikatakan polimorfik (beragam) jika frekuensi alel diatas 0,01.

\section{Bentuk Jengger pada Ayam Kampung}

Polong merupakan bentuk jengger keragaman dalam suatu populasi dapat dilihat dari nilai heterosigositas, semakin tinggi nilai heterosigositas karakteristik genetik eksternal maka semakin tinggi keragaman suatu populasi. Keberagaman dari sifat kualitatif warna dan pola bulu yang paling banyak ditemukan di Minahasa dengan persentase jantan 53,89\% dan betina $63,2 \%$. Berbeda dengan hasil penelitian dari Johari et al. (2009) dan Suhardi (2011) dimana bentuk jengger yang paling banyak ditemui adalah jengger tunggal.

Nilai heterosigositas bentukjengger ayam Kampung di Minahasa berkisar 0,11 sampai 0,49 yang dapat tergolong sedang sampai tinggi dan mengidikasikan derajat 
Tabel 8. Frekuensi Genetik dan Heterosigositas Warna cuping pada Ayam Kampung di Minahasa

\begin{tabular}{ccccccc}
\hline Fenotipe & Sex & $\mathrm{n}$ & $\%$ & $\mathrm{P}$ & $\mathrm{q}$ & $\mathrm{H}$ \\
\hline Merah & $\hat{0}$ & 153 & 91,62 & 0,26 & 0,74 & 0,38 \\
& 0 & 116 & 92,8 & 0,14 & 0,86 & 0,24 \\
Putih-merah & + & 14 & 8,38 & 0,78 & 0,22 & 0,35 \\
& 0 & 9 & 7,2 & 0,76 & 0,24 & 0,36 \\
\hline
\end{tabular}

Keterangan: n; jumlah sampel $\delta^{1}$ : jantan (167),, : betina (125), p: frekuensi gen dominan, q: frekuensi gen resesif, $\mathrm{H}$ : heterosigositas

perkawinan inbreeding cukup rendah. Frekuensi gen dominan pada sifat kualitatif bentuk jengger menunjukkan angka diatas 0,01 , hal ini berarti bentuk jengger ayam kampung yang ada di Minahasa masih sangat beragam. Bentuk jengger padaayam kampung ditentukan oleh 2 jenis gen pada 2 kromosom yang berbeda yaitu gen bentuk jengger Mawar (R) dan bentuk jengger Polong (P) (Maharani et al., 2019).

\section{Warna Cuping pada Ayam Kampung}

Dalam penelitian ini warna cupping ayam kampung yang terdapat di Minahasa lebih dominan warna cupping merah (Tabel 8) Nilai heterosigositas warna cuping ayam Kampung di Minahasa berkisar 0,24 sampai 0,38 yang dapat tergolong sedang dan mengidikasikan derajat perkawinan inbreeding terjadi relatif cukup tinggi. Dapat dilihat pada Tabel 8 bahwafrekuensi gen dominan pada cuping berwarna merah maupun putih-merah menunjukan keberagaman yang tinggi. Penelitian ini tidak jauh berbeda dengan penelitian yang dilaksanakan Rafian dan Ulupi (2017) yaitu warna cuping yang paling banyak ditemukan adalah warna merah dengan persentase ayam jantan $46 \%$ dan betina 86\%. Menurut Arlina et al. (2014) sebagian besar breed ayam mempunyai cuping berwarna merah.

\section{Warna Kulit Kaki (Shank) pada Ayam Kampung}

Frekuensi gen dan nilai heterosigositas dari warna kulit kaki (shank) disajikan pada Tabel 9. Frekuensi gen dominan pada kulit kaki (shank) berwarna kuning maupun hitam menunjukkan angka diatas 0,01 yang berarti warna kulit kaki (shank) keberagaman.

Nilai heterosigositas Warna kulit kaki (shank) pada ayam kampung di Minahasa berkisar 0,36 sampai 0,50 yangdapat tergolong tinggi dan mengidikasikan derajat perkawinan 
Tabel 9. Frekuensi Genetik dan Heterosigositas Warna Shank pada Ayam Kampung di Minahasa

\begin{tabular}{lcccccc}
\hline Fenotipe & Sex & $\mathrm{n}$ & $\%$ & $\mathrm{P}$ & $\mathrm{Q}$ & $\mathrm{H}$ \\
\hline Kuning & $\hat{0}$ & 124 & 74,25 & 0,33 & 0,67 & 0,44 \\
& + & 92 & 73,60 & 0,23 & 0,77 & 0,36 \\
\multirow{3}{*}{ Hitam } & के & 43 & 25,75 & 0,61 & 0,39 & 0,48 \\
& ○े & 33 & 26,40 & 0,54 & 0,46 & 0,50 \\
\hline
\end{tabular}

Keterangan: $\mathrm{n}$; jumlah sampel $\delta^{\Uparrow}$ : jantan (167),, : betina (125), p: frekuensi gen dominan, q: frekuensi gen resesif, $\mathrm{H}$ : heterosigositas

inbreeding cukup rendah dalam kaitan sifat kualitatif ini. Penelitian ini sesuai dengan hasil penelitian yang dilakukan Arlina et al. (2014) bahwa warna kulit kaki (shank) ayam kampung yang dominan adalah warna kuning. Sartika et al. (2008) mengemukakan bahwa karakteristik warna kuning atau putih disebabkan oleh kurangnya kandungan melanin pada jaringan kulit, kandungan melanin pada kulit dikontrol oleh gen resesif terkait kelamin dalam keadaan homozigot atau heterozigot.

\section{Bentuk Taji pada Ayam Kampung Di Kabupaten Minahasa}

Hasil penelitian ini menunjukkan taji hanya ditemukan pada ayam jantan saja (Tabel 10). Walaupun demikian, dilihat dari nilai frekuensi dan nilai heterosigositas sifat kualitatif bentuk taji yang berada diatas 0.01 mengindikasikan bahwa tingkat keberagaman sifat kualitatif bentuk taji pada ayam kampung di Minahasa cukup tinggi.

Tabel 10. Frekuensi Genetik dan Heterosigositas Bentuk Taji pada Ayam Kampung di Minahasa

\begin{tabular}{|c|c|c|c|c|c|c|}
\hline Fenotipe & Sex & $\mathrm{N}$ & $\%$ & $\mathrm{P}$ & $\mathrm{q}$ & $\mathrm{H}$ \\
\hline Taji & $\begin{array}{l}\hat{0} \\
0 \\
+\end{array}$ & 47 & 28,14 & 0,59 & 0,41 & 0,48 \\
\hline Keplek & $\begin{array}{l}1 \\
0 \\
0\end{array}$ & 53 & 31,74 & 0,56 & 0,44 & 0,49 \\
\hline Tidak ada taji & $\begin{array}{l}\hat{0} \\
0 \\
+\end{array}$ & $\begin{array}{l}67 \\
125\end{array}$ & $\begin{array}{l}40,12 \\
100\end{array}$ & $\begin{array}{l}0,51 \\
0,11\end{array}$ & $\begin{array}{l}0,49 \\
0,89\end{array}$ & $\begin{array}{l}0,50 \\
0,19\end{array}$ \\
\hline
\end{tabular}

Keterangan: $n$; jumlah sampel $\delta^{1}$ : jantan (167), ${ }^{\circ}$ : betina (125), p: frekuensi gen dominan, q: frekuensi gen resesif, $\mathrm{H}$ : heterosigositas 
Nilai heterosigositas bentuk taji pada ayam Kampung di Minahasa berkisar 0,19 sampai 0,50 yang dapat tergolong sedang sampai tinggi dan mengidikasikan derajat perkawinan inbreeding cukup rendah dalam kaitan sifat kualitatif ini. Rataan heterosigositas hasil observasi dalam kajian yang bervariasi dalam penelitian ini berkisar 0,19 sampai 0,50 dan masih lebih rendah dibandingkan heterosigositas yang diharapkan sekitar 0,88 (Dorak, 2006). Derajat heterogenitas genetik yang rendah dapat mengarahkan pada kondisi peluang terjadi inbreeding agak tinggi dalam populasi. Selanjutnya, derajat inbreeding tinggi dalam populasi dapat menyebabkan hybrid vigour ternak menurun (Noor, 2008). Kondisi ini terlihat pada frekuensi genotip yang berada dalam keadaan tidak seimbang melalui uji Chi Square yang mngindikasikan kemungkinan banyak terjadi persilangan inbreeding dalam populasi ternak ayam Kampung di Kabupaten Minahasa.

\section{KESIMPULAN}

Sifat kualitatif ayam Kampung di Kabupaten Minahasa menunjukkan tingkat keberagaman yang cukup tinggi, heterosigositas sedang $(0,42)$, belum berada dalam keseimbangan genetik dalam populasi, kecuali sebaran pewarisan sifat fenotip warna kuping dan warna kulit kaki.

\section{DAFTAR PUSTAKA}

Amlia, M., P. Amrulah dan R. Aka. 2016. Studi karakteristik sifat kualitatif dan sifat kuantitatif di Kecamatan Lasalimu Kabupaten Buton. Jurnal Ilmu dan Teknologi Peternakan 3(1): 31-39.

Arlina F., H. Abash, S. Anwar, Jamsari. 2014. Variability of external genetic characteristic of Kokok Balenggek Chicken in West Sumatra, Indonesia. International Journal of Poultry Science 13(4):185-190.

Dako, S., F. Datau, S. Nathan, N. K. Laya. 2020. Keseimbangan genetic eksternal pada ayam hasil silangan. Jambura Journal of Animal Science 2(2): 76-88.

Dorak, M.T. 2006. Basic Population Genetics.www.dorak.info/genetics/ popgen.html

Johari, S., Sutopo dan A. Santi. 2009. Frekuensi fenotipik sifat-sifat kualitatif ayam kedu dewasa. Jurnal Universitas Diponegoro. 13(2):606616.

Mansjoer, S. S. 1985. Pengkajian sifat-sifat produksi ayam Kampung serta persilangannya dengan ayam Rhode Island Red (RIR). Disertasi. Fakultas Pasca Sarjana. Institute Pertanian Bogor, Bogor. Hlm: 90130.

Naatamijaya, A. G. 2010. Pengembangan potensi ayam lokal untuk menunjang peningkatan kesejahteraan petani. Jurnal Litbang Pertanian 29(4): 131-138.

Nangoy, M. M., M. E. R. Montong., W. Utiah., M. N. Regar. 2017. Pemanfaatan tepung manure hasil degradasi larva lalat hitam 
(Hermetia illucens L.) terhadap performens ayam kampung fase layer. Jurnal Zootek 37(2): 370377.

Nishida, T., K. Nozawa., Y. Hayasi., T. Hashiguchi, and S. S Mansjoer. 1982. Body measurement and analis on external genetic characters of Indonesian native fowl. Journal The Originand Phylogeny of Indonesian Native Livestock 1(1): 47-40.

Noor, R, R. 2008. Genetika Ternak.Penebar Swadaya. Jakarta

Rafian, T dan N. Ulupi. 2017.Keragaman sifat kualitatif ayam burgo di Provinsi Bengkulu. Jurnal Sains Peternakan Indonesia 12(1): 47-54

Sartika, T., D. K. Wati, H. S. Iman Rahayu dan S. Iskandar. 2008. Perbandingan genetic eksternal ayam wareng dan ayam kampung yang dilihat dari laju introgresi dan variabilitas genetiknya. Jurnal Ilmu Ternak dan Veteriner 13(4): 279-287.

Subekti, K dan F. Arlina. 2011. Karakteristik genetik eksternal ayam Kampung di Kecamatan Sungai Pagu Kabupaten Solok Selatan. Jurnal Ilmiah Ilmu-Ilmu Peternakan 14(2): 74-86.

Suhardi. 2011. Karakteristik ex situ ayam lokal khas Dayak bagi pengembangan plasma nutfah ternak unggas Nasional. Jurnal Teknologi Pertanian 7(1): 36-41.

Tamzil, M. H., R. R. Noor, P. S. Hardjosworo, W. Manalu., C. Sumatri. 2013. Keragaman gen heat schock protein 70 pada ayam kampung, ayam Arab, dan ayam ras. Jurnal Veteriner 14 (3):317326.

Van Vleck, L.D., E.J. Pollak and E.A.B. Oltnacu. 1987. Genetics for the Animal Science. W. H. Freemanand Company, NewYork. 